\title{
The Kluyveromyces lactis $\gamma$-toxin targets tRNA anticodons
}

\author{
JIAN LU, BO HUANG, ANDERS ESBERG, MARCUS J.O. JOHANSSON, and ANDERS S. BYSTRÖM
}

Department of Molecular Biology, Umeå University, 90187 Umeå, Sweden

\begin{abstract}
Kluyveromyces lactis killer strains secrete a heterotrimeric toxin (zymocin), which causes an irreversible growth arrest of sensitive yeast cells. Despite many efforts, the target(s) of the cytotoxic $\gamma$-subunit of zymocin has remained elusive. Here we

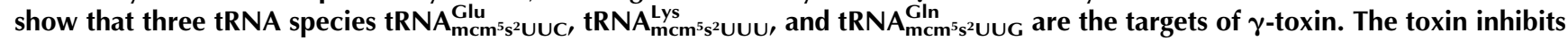
growth by cleaving these tRNAs at the $3^{\prime}$ side of the modified wobble nucleoside 5-methoxycarbonylmethyl-2-thiouridine $\left(\mathrm{mcm}^{5} \mathrm{~s}^{2} \mathrm{U}\right)$. Transfer RNA lacking a part of or the entire $\mathrm{mcm}^{5}$ group is inefficiently cleaved by $\gamma$-toxin, explaining the $\gamma$-toxin resistance of the modification-deficient trm9, elp1-elp6, and kti11-kti13 mutants. The K. lactis $\gamma$-toxin is the first eukaryotic toxin shown to target tRNA.
\end{abstract}

Keywords: K. lactis $\gamma$-toxin; tRNA endonuclease; ELP3; TRM9; 5-methoxycarbonylmethyl-2-thiouridine

\section{INTRODUCTION}

Many microorganisms produce toxic substances to gain a competitive growth advantage. Killer strains of the dairy yeast Kluyveromyces lactis secrete a heterotrimeric toxin (zymocin), which causes an irreversible arrest of sensitive yeast cells, such as Saccharomyces cerevisiae in the unbudded $\left(G_{1}\right)$ phase of the cell cycle (Gunge et al. 1981; Sugisaki et al. 1983; White et al. 1989; Schaffrath and Meinhardt 2005). Zymocin consists of three subunits, $\alpha, \beta$, and $\gamma$, that are encoded by a linear plasmid (Gunge et al. 1981; Stark et al. 1990). Upon secretion, the $\alpha$ - and $\beta$-subunits dock the zymocin to the cell wall of susceptible yeasts and facilitate transfer of the $\gamma$-subunit (Schaffrath and Meinhardt 2005). Cytotoxicity resides within the $\gamma$-subunit, since intracellular expression of the $\gamma$-toxin mimics the action of exogenous zymocin (Tokunaga et al. 1989; Butler et al. 1991a).

Two classes of $S$. cerevisiae mutants resistant to zymocin have been described (Butler et al. 1991a, 1994), but the mechanism of $\gamma$-toxin-induced growth arrest is not clear (Sugisaki et al. 1983; White et al. 1989; Schaffrath and Meinhardt 2005). Class I resistant mutants are defective in

Reprint requests to: Anders S. Byström, Department of Molecular Biology, Umeå University, 90187 Umeå, Sweden; e-mail: Anders.Bystrom@molbiol. umu.se; fax 46-90-77-26-30.

Article and publication are at http://www.rnajournal.org/cgi/doi/10.1261/ rna.2172105. binding and/or uptake of zymocin but are sensitive to endogenous expression of the $\gamma$-toxin. Class II mutants are believed to be target site mutants as they are resistant to both exogenous zymocin and endogenous $\gamma$-toxin. Strains with mutations in any of the six Elongator protein subunit genes (ELP1-ELP6) or the three killer toxin insensitivity genes (KTI11-KTI13) are class II mutants (Butler et al. 1994; Frohloff et al. 2001; Jablonowski et al. 2001). The Elongator complex has been implicated in elongation of RNA polymerase II (Pol II) transcription (Otero et al. 1999) and in regulation of exocytosis (Rahl et al. 2005). A model was proposed where the $\gamma$-toxin is targeted to Pol II by the Elongator complex, which would lead to a transcriptional inactivation of genes important for $G_{1}$ exit (Schaffrath and Meinhardt 2005). However, this model is not easily reconciled with the evidence that the Elp1-Elp6 and Kti11-Kti13 proteins are all required for formation of 5methoxycarbonylmethyl $\left(\mathrm{mcm}^{5}\right)$ and 5-carbamoylmethyl $\left(\mathrm{ncm}^{5}\right)$ groups on uridines at the wobble position in tRNA (Huang et al. 2005). These data rather suggest that phenotypes induced by mutations in the ELP1-ELP6 and KTI11-KTI13 genes could be a consequence of hypomodified tRNAs (Huang et al. 2005).

In this report we show that three tRNA speciestRNA $\mathrm{mcm}^{5} \mathrm{~s}^{2} \mathrm{UUC}, \mathrm{tRNA}_{\mathrm{mcm}}^{\mathrm{Lys} \mathrm{s}^{2} \mathrm{UUU}}$, and $\mathrm{tRNA}_{\mathrm{mcm}}^{\mathrm{Gln} \mathrm{s}^{2} \mathrm{UUG}}-$ are cleaved by $\gamma$-toxin at the $3^{\prime}$ side of the modified wobble nucleoside 5-methoxycarbonylmethyl-2-thiouridine $\left(\mathrm{mcm}^{5} \mathrm{~s}^{2} \mathrm{U}\right)$. The $\mathrm{mcm}^{5}$ side-chain is important for 
efficient cleavage of the target tRNAs, explaining the $\gamma$ toxin resistance of mutants defective in synthesis of this group.

\section{RESULTS AND DISCUSSION}

We previously showed that the class II zymocin-resistant elp1-elp6 and kti11-kti13 mutants are deficient in formation of $\mathrm{mcm}^{5}$ (Fig. 1A) and $\mathrm{ncm}^{5}$ side-chains at wobble uridines in tRNA (Huang et al. 2005). Interestingly, a strain deleted for the TRM9 gene encoding a methyltransferase responsible for the last step in the synthesis of the wobble $\mathrm{mcm}^{5}$ side-chain (Fig. 1A; Kalhor and Clarke 2003) is also a class II resistant mutant (Figs. 1B, 2E). Although the zymocin resistance is comparable between elp3 and trm 9 mutants (Figs. 1B, 2E), there are clear differences in growth rates and phenotypes (data not shown). Lack of the entire $\mathrm{mcm}^{5}$ group at the wobble position prevents an ochre suppressor tRNA from reading ochre stop codons (Huang et al. 2005).
A

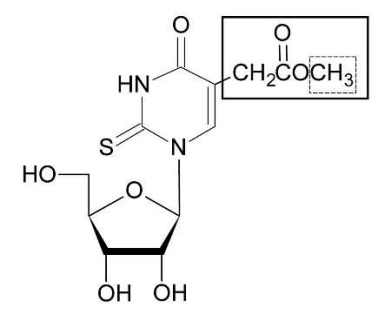

\section{B}

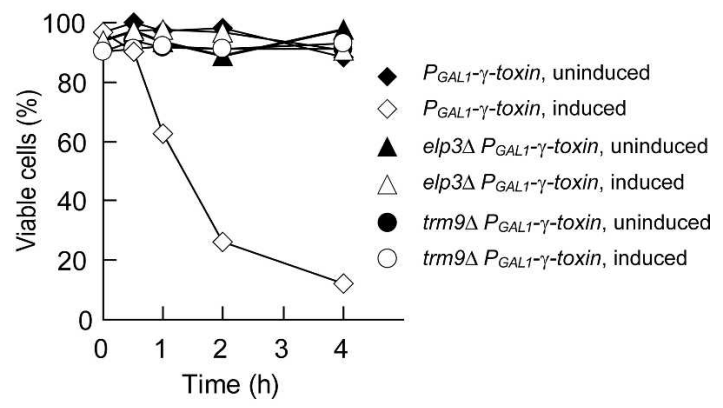

C

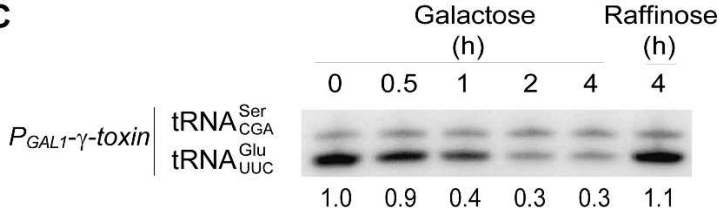

\begin{tabular}{c|c} 
elp3s & tRNA \\
$P_{\text {GAL } 1-\gamma \text {-toxin }}^{\text {Ser }}$ & tRNA \\
Glu
\end{tabular}

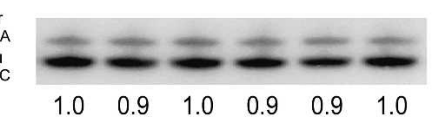

\begin{tabular}{c|c} 
trm9 & tRNA \\
$P_{\text {GAL1- } \gamma \text {-toxin }}^{\text {Ser }}$ & tRNA \\
Glu
\end{tabular}

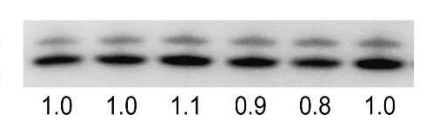

FIGURE 1. Intracellular $\gamma$-toxin expression in S. cerevisiae reduces cell viability and the level of $\mathrm{tRNA}_{\mathrm{mcm}}^{\mathrm{Glu} \mathrm{s}^{2} \mathrm{UUC}}$. (A) Structure of $\mathrm{mcm}^{5} \mathrm{~s}^{2} \mathrm{U}$. An $e$ elp $3 \Delta$ mutant lacks the entire $\mathrm{mcm}^{5}$ side-chain (box with solid lines) (Huang et al. 2005), whereas a trm9 $9 \Delta$ strain lacks the indicated methyl group (box with dotted lines) (Kalhor and Clarke 2003). The formation of the 2-thio group appears not to be affected in the elp3 and trm9 mutants (Huang et al. 2005; data not shown). (B) Wild-type, elp $3 \Delta$, and trm $9 \Delta$ strains with an integrated $P_{G A L 1}-\gamma$-toxin construct were shifted from raffinose (uninduced) to galactose (induced) containing medium. The ratio of viable to total cells was determined at indicated time points. $(C)$ Northern blot analysis of total RNA isolated from the induced or uninduced cultures in $B$. The $\mathrm{RRNA}_{\mathrm{mcm}^{5} \mathrm{~s}^{2} \mathrm{UUC}}^{\mathrm{Glu}}$ signal was quantified and normalized to the tRNA $\mathrm{CGA}_{\mathrm{CH}}$ signal. Below each lane is the normalized value expressed relative to the corresponding value at time point 0 , which is set to 1 . et al. 2005).
In contrast, a deletion of the TRM9 gene does not abolish the ability of the suppressor tRNA to read ochre stop codons (data not shown). Thus, class II zymocin resistance correlates with a defect in synthesis of $\mathrm{mcm}^{5}$ side-chain but not with a general translational defect, indicating that $\mathrm{RNA}(\mathrm{s})$ containing this side-chain could be the target(s) of $\gamma$-toxin. Interestingly, high dosage of a gene encoding $\mathrm{RNA}_{\mathrm{mcm}^{5} \mathrm{~s}^{2} \mathrm{GUC}}^{\mathrm{Glu}}$ suppresses the zymocin sensitivity of a -type S. cerevisiae strain (Butler et al. 1994), suggesting

To investigate the hypothesis that $\mathrm{tRNA}_{\mathrm{mcm}}^{\mathrm{Glu}} \mathrm{s}^{2} \mathrm{UUC}$ is a target of the $\gamma$-toxin, we analyzed the levels of this tRNA in wild-type, elp $3 \Delta$, and $\operatorname{trm} 9 \Delta$ cells after induction of an integrated $\gamma$-toxin gene placed under the control of the $P_{\text {GALI }}$ promoter. Similar to exogenous zymocin treatment (White et al. 1989), the viability of wild-type cells opped after induction of $\gamma$-toxin expression (Fig. 1B). Northern blot analysis showed that the amount of $\mathrm{tRNA}_{\mathrm{mcm}}^{\mathrm{Glu}} \mathrm{s}^{2} \mathrm{UuC}$ decreased with increased induction time (Fig. 1C). Since these phenotypes were not a general consequence of growth in galactose media (data not shown) and not observed in the uninduced control (Fig. 1B,C), they are a result of $\gamma$-toxin expression. Furthermore, a decrease in the levels of $\mathrm{tRNA}_{\mathrm{mcm}}^{\mathrm{Glu} \mathrm{s}^{2} \mathrm{UUC}}$ was observed in wild-type cells treated with exogenous zymocin, showing that intracellular $\gamma$ toxin expression mimics zymocin treatment (data not shown). Interestingly, no reduction in cell viability or tRNA ${ }^{\text {Glu }}$ levels was observed upon $\gamma$-toxin induction in the elp $3 \Delta$ and trm $9 \Delta$ mutants (Fig. 1B,C), supporting the idea that the $\mathrm{mcm}^{5}$ side-chain in $\mathrm{tRNA}_{\mathrm{mcm}^{5} \mathrm{~s}^{2} \mathrm{UuC}}^{\mathrm{Glu}}$ is required for the cytotoxicity of $\gamma$ toxin. In addition to $\mathrm{tRNA}_{\mathrm{mcm}}^{\mathrm{Glu}} \mathrm{s}^{2} \mathrm{UUC}$, a $\mathrm{mcm}^{5}$ side-chain can be found in $\mathrm{tRNA}_{\mathrm{mcm}^{5} \mathrm{~s}^{2} \mathrm{UUU}}^{\mathrm{Lys}, \mathrm{tRNA}} \mathrm{mcm}_{\mathrm{mcm}^{5} \mathrm{~s}^{2} \mathrm{UUG}}^{\mathrm{Gln}}$ tRNA mcm $^{\text {GlycC, }}$ and tRNA mcm $^{\text {Arg }}$ UCU (Johansson and Byström 2005; data not shown). No obvious reduction in the levels of $\mathrm{tRNA}_{\mathrm{mcm}}^{\mathrm{Lys} \mathrm{s}^{2} \mathrm{UUU}}$, $\mathrm{RNA}_{\mathrm{mcm}}^{\mathrm{Gln}} \mathrm{Gs}^{5} \mathrm{UUG}$, $\mathrm{tRNA}_{\mathrm{mcm}^{\mathrm{S}} \mathrm{UCC} \text {, or }}^{\mathrm{Gly}}$ tRNA $\mathrm{mcm}^{\mathrm{Arg}} \mathrm{UCU}$ was observed after $4 \mathrm{~h}$ of $\gamma$-toxin induction in wild-type cells (data not shown).

The reduction of $\mathrm{tRNA}_{\mathrm{mcm}^{5} \mathrm{~s}^{2} \mathrm{UUC}}^{\mathrm{Glu}}$ in vivo could be a direct effect of $\gamma$-toxin or a secondary effect of growth arrest. To investigate if $\gamma$-toxin acts directly on tRNA, we purified a recombinant glutathione-S-transferase (GST) tagged $\gamma$ toxin from Escherichia coli (Fig. 2A, lane 
1). The 53-kDa $\gamma$-toxin-GST fusion protein was further purified (Fig. 2A, lane 2) by using a gel filtration column. The $\gamma$-toxin-GST protein fraction, 53-kDa $\gamma$-toxin-GST, or GST (Fig. 2A) was incubated with total tRNA prepared from wild-type $S$. cerevisiae cells. Northern blot analysis showed that the amount of full length $\mathrm{tRNA}_{\mathrm{mcm}^{5} \mathrm{~s}^{2} \mathrm{GUC}}^{\mathrm{Glu}}$ decreased upon treatment with $\gamma$-toxin-GST fraction or $53-\mathrm{kDa} \gamma$ toxin-GST but not upon treatment with GST (Fig. 2B,C). Interestingly, $\gamma$-toxin-dependent signals at the approximate sizes of 34 (using a $5^{\prime}$ probe) and 41 (using a $3^{\prime}$ probe) nucleotides were detected (Fig. 2B,C), suggesting that $\mathrm{tRNA}_{\mathrm{mcm}^{5} \mathrm{~s}^{2} \mathrm{UUC}}^{\mathrm{Glu}}$ is cleaved by the $\gamma$-toxin. The $\mathrm{tRNA}_{\mathrm{mcm}}^{\mathrm{Glu} \mathrm{s}^{2} \mathrm{UUC}}$ halves were not detected upon $\gamma$-toxin induction in vivo, suggesting that the cleavage products are rapidly turned over.

To investigate the influence of the wobble $\mathrm{mcm}^{5}$ sidechain on tRNA cleavage in vitro, the $\gamma$-toxin-GST fraction was serially diluted and incubated with total tRNA prepared from wild-type, elp $3 \Delta$, or $\operatorname{trm} 9 \Delta$ cells. The hypomodified tRNA $^{\text {Glu }}$ was cleaved at high $\gamma$-toxin concentrations in vitro, but based on the dilution series at a lower efficiency than the fully modified counterpart (Fig. 2D). Interestingly, at high $\gamma$-toxin concentrations, we also observed cleavage of the fully modified tRNA $\mathrm{mcm}^{\mathrm{Lys}} \mathrm{s}^{2} \mathrm{UUU}$ and $\mathrm{tRNA}_{\mathrm{mcm}}^{\mathrm{Gln}} \mathrm{s}^{2} \mathrm{UUG}$ (Fig. 2D). Similar to tRNA ${ }^{\text {Glu }}$, hypomodified tRNA ${ }^{\text {Lys }}$ and tRNA $^{\mathrm{Gln}}$ were inefficiently cleaved. Although tRNA $\mathrm{mcm}^{5} \mathrm{~s}^{2} \mathrm{UUU}$ and $\mathrm{tRNA}_{\mathrm{mcm}}^{\mathrm{Gln} \mathrm{s}^{2} \mathrm{UUG}}$ are cleaved by $\gamma$ toxin, tRNA $\mathrm{mcm}^{5} \mathrm{~s}^{2} \mathrm{UUC}$ appears to be the best substrate since cleavage was detected at significantly lower $\gamma$-toxin concentrations. No in vitro cleavage of $\mathrm{RNA}_{\mathrm{mcm}}^{\mathrm{Gly}} \mathrm{UCC}$ or $\mathrm{tRNA}_{\mathrm{mcm}^{5} \mathrm{UCU}}^{\mathrm{Arg}}$ was observed even at the highest $\gamma$-toxin concentration (data not shown), suggesting that features other than the $\mathrm{mcm}^{5}$ side-chain contribute to the substrate

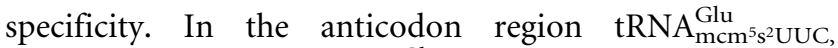
$\mathrm{tRNA}_{\mathrm{mcm}^{5} \mathrm{~s}^{2} \mathrm{UUU}}^{\mathrm{Lys}}$, and $\mathrm{tRNA}_{\mathrm{mcm}}^{\mathrm{Gln}} \mathrm{s}^{2} \mathrm{UUG}$ share the sequence $\mathrm{U}_{33} \mathrm{mcm}^{5} \mathrm{~s}^{2} \mathrm{U}_{34} \mathrm{U}_{35}$ (Fig. 3C). The tRNA $\mathrm{mcm}^{\mathrm{Gly}} \mathrm{CC}$ and $\mathrm{tRNA}_{\mathrm{mcm}}^{\mathrm{Arg}} \mathrm{UCU}$ species lack the 2-thio group at position 34 and contain a $\mathrm{C}$ at position 35 , implying that not only the $\mathrm{mcm}^{5}$ side-chain but also the 2-thio group and the primary sequence of the anticodon region could be important for recognition and/or cleavage by $\gamma$-toxin.

Consistent with the different $\gamma$-toxin reactivity of the substrate tRNAs in vitro, elevated levels of $t R N A_{\mathrm{mcm}^{5} \mathrm{~s}^{2} \mathrm{UUC}}^{\mathrm{Glu}}$, but not $\mathrm{tRNA}_{\mathrm{mcm}^{5} \mathrm{~s}^{2} \mathrm{UUU}}^{\mathrm{Lys}}$ or $\mathrm{tRNA}_{\mathrm{mcm}^{5} \mathrm{~s}^{2} \mathrm{GUG}}^{\mathrm{Gln}}$, rendered a wild-type strain resistant to exogenous zymocin (Fig. 2E). Simultaneous overexpression of $\mathrm{tRNA}_{\mathrm{mcm}}^{\mathrm{Lys} \mathrm{s}^{2} \mathrm{UUU}}$ and $\mathrm{tRNA}_{\mathrm{mcm}^{5} \mathrm{~s}^{2} \mathrm{UUG}}^{\mathrm{Gln}}$ generated a resistance comparable to that observed for increased dosage of the $\mathrm{RNA}_{\mathrm{mcm}^{5} \mathrm{~s}^{2} \mathrm{UUC}}^{\mathrm{Glu}}$ gene. Moreover, overexpression of $\mathrm{tRNA}_{\mathrm{mcm}^{5} \mathrm{~s}^{2} \mathrm{UUC}}^{\mathrm{Glu}}$ in combination with $\mathrm{tRNA}_{\mathrm{mcm} \mathrm{s}^{2} \mathrm{LUU}}^{\mathrm{Lys}}$ or $\mathrm{tRNA}_{\mathrm{mcm}}^{\mathrm{Gln} \mathrm{s}^{2} \mathrm{UUG}}$ or all three tRNA species together generated higher zymocin resistance than did elevated expression of tRNA $\mathrm{mcm}^{\mathrm{Glu} \mathrm{s}^{2} \mathrm{UUC}}$ alone (Fig. $2 \mathrm{E})$. These data indicate that not only $\mathrm{RNA}_{\mathrm{mcm}^{5} \mathrm{~s}^{2} \mathrm{UUC}}^{\mathrm{Glu}}$ but also tRNA $\mathrm{mcm}^{5} \mathrm{~s}^{2} \mathrm{UUU}$ and $\mathrm{tRNA}_{\mathrm{mcm}^{5} \mathrm{~s}^{2} \mathrm{UUG}}^{\mathrm{Gln}}$ are $\gamma$-toxin substrates in vivo.
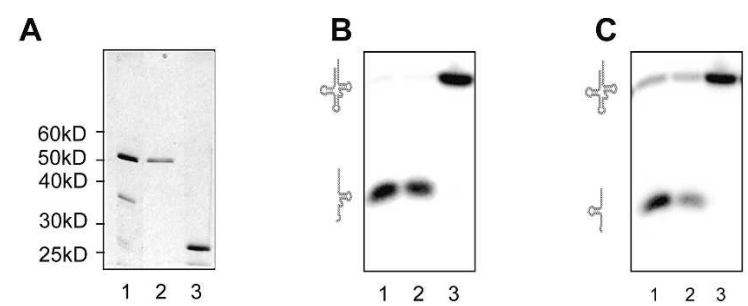

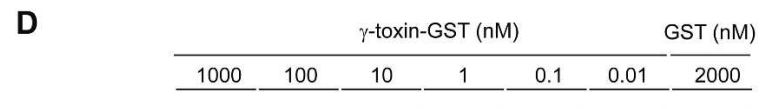
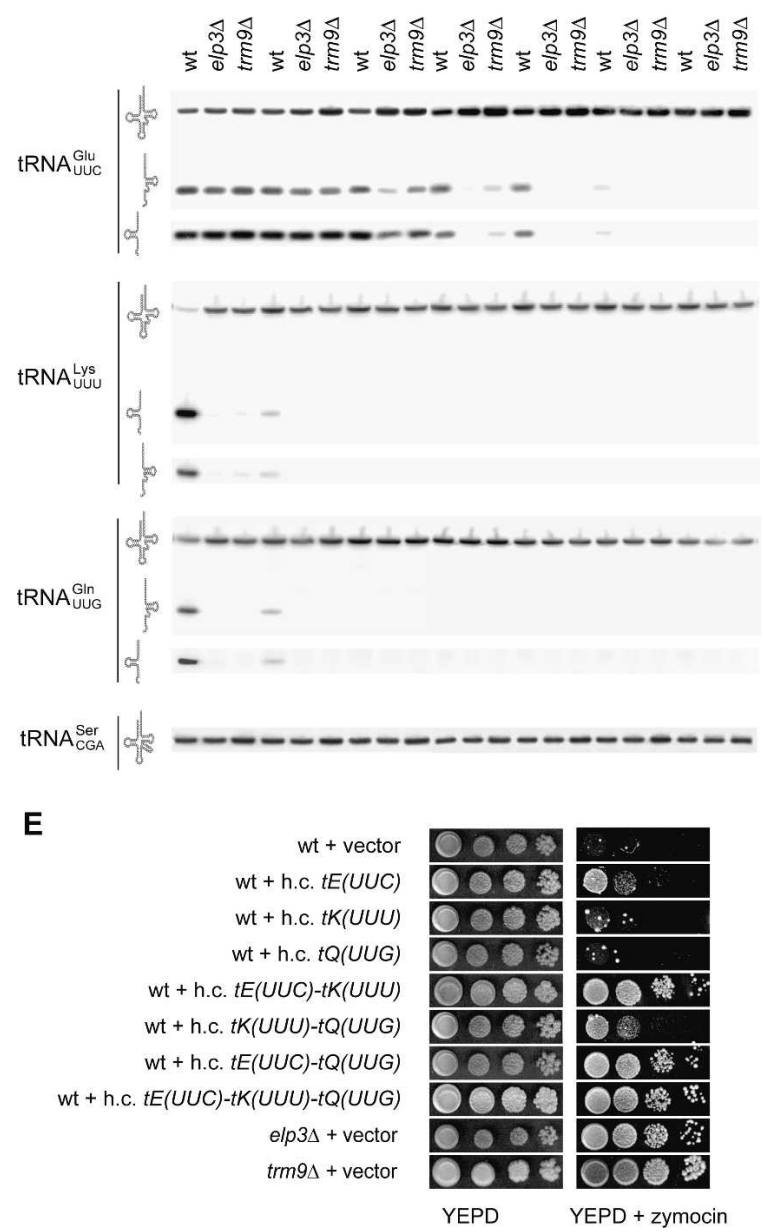

FIGURE 2. The $\gamma$-toxin is an endonuclease that cleaves tRNA $\mathrm{mcm}^{\mathrm{Glu}} \mathrm{s}^{2} \mathrm{UUC}$, $\mathrm{tRNA}_{\mathrm{mcm}}^{\mathrm{Lys}} \mathrm{s}^{2} \mathrm{UUU}$, and tRNA $\mathrm{mcm}^{\mathrm{Gln}} \mathrm{s}^{2} \mathrm{UUG}$. (A) SDS-PAGE analysis of $\gamma$-toxin-GST fraction (lane 1), further purified $53-\mathrm{kD} \gamma$ toxin-GST (lane 2), and GST (lane 3). Proteins were visualized by silver staining. $(B, C)$ Northern blot analysis of wild-type $S$. cerevisiae tRNA $(5 \mu \mathrm{g})$ incubated with $1 \mu \mathrm{g}$ of $\gamma$-toxin-GST fraction (lane 1), 53-kDa $\gamma$-toxin-GST (lane 2), or GST (lane 3) for $10 \mathrm{~min}$ at $30^{\circ} \mathrm{C}$. The filter was probed by using an oligonucleotide complementary to the $3^{\prime}-(B)$ or the $5^{\prime}$-part $(C)$ of tRNA $\mathrm{mcm}^{\mathrm{Glu}} \mathrm{s}^{2} \mathrm{UUC}$. $(D)$ Reactions containing the indicated concentration of $\gamma$-toxin-GST fraction or GST, and $5 \mu \mathrm{g}$ of wild-type, elp $3 \Delta$, or trm $9 \Delta$ total tRNA was incubated for $10 \mathrm{~min}$ at $30^{\circ} \mathrm{C}$. Samples were analyzed by Northern blots; the identity of each signal is indicated on the left. (E) A wild-type $S$. cerevisiae strain CY4029 (W303-1A SSD1-v1) carrying the indicated high copy (h.c.) plasmid was serially diluted, spotted onto a YEPD plate or a YEPD plate supplemented with crude zymocin, and incubated for $3 \mathrm{~d}$ at $25^{\circ} \mathrm{C}$. The elp $3 \Delta$ and $\operatorname{trm} 9 \Delta$ strains carrying the empty h.c. vector were included on the plates. 
To determine the position of the cleavage, we performed primer extension analysis by using $\gamma$-toxin-treated total wildtype tRNA and an oligonucleotide complementary to the $3^{\prime}$ end of tRNA $\mathrm{mcm}^{5} \mathrm{~s}^{2} \mathrm{UUC}$, $\mathrm{tRNA}_{\mathrm{mcm}^{5} \mathrm{~s}^{2} \mathrm{UUU}}^{\mathrm{Lys}}$, or tRNA $\mathrm{mcm}^{5} \mathrm{~s}^{2} \mathrm{GUG}$. The size of the major products showed that the $5^{\prime}$ nucleotide of the $3^{\prime}$-halves corresponds to position 35 in
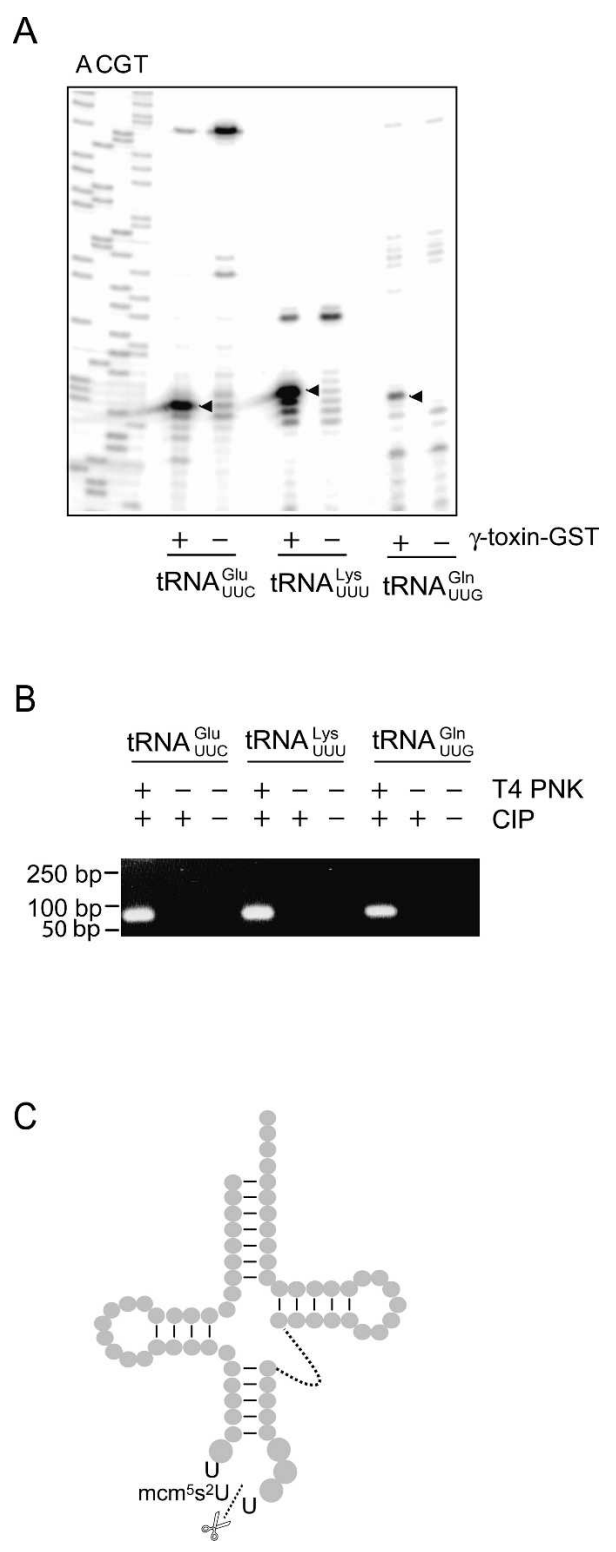

FIGURE 3. K. lactis $\gamma$-toxin cleaves tRNA $\mathrm{mcm}^{\mathrm{Glu}} \mathrm{s}^{2} \mathrm{UUC}$, $\mathrm{tRNA}_{\mathrm{mcm}}^{\mathrm{Lys}} \mathrm{s}^{2} \mathrm{UUU}$, and tRNA $\mathrm{mcm}^{5} \mathrm{~s}^{2} \mathrm{UUG}$ between position 34 and 35 . (A) $\gamma$-toxin-GSTtreated $(+)$ or mock-treated $(-)$ wild-type total tRNA was reverse transcribed by using ${ }^{32} \mathrm{P}$-labeled oligonucleotides complementary to the $3^{\prime}$-end of tRNA $\mathrm{mcm}^{\mathrm{Glu}} \mathrm{s}^{2} \mathrm{UUC}$, $\mathrm{tRNA}_{\mathrm{mcm}^{5} \mathrm{~s}^{2} \mathrm{LUU}}^{\mathrm{Lys}}$, or tRNA $\mathrm{mcm}^{\mathrm{Gln}} \mathrm{s}^{2} \mathrm{UUG}$. The sequence ladder was derived from a gene coding for $t R N A_{\mathrm{mcm}^{5} s^{2} U U C}^{\mathrm{Glu}^{2}}$ Arrowheads indicate reverse transcripts induced by $\gamma$-toxin treatment. (B) The purified $5^{\prime}$-half of $\mathrm{tRNA}_{\mathrm{mcm}}^{\mathrm{Glu} \mathrm{s}^{2} \mathrm{UUC}}$, $\mathrm{tRNA}_{\mathrm{mcm}}^{\mathrm{Lys}} \mathrm{s}^{2} \mathrm{UUU}$, or $\mathrm{tRNA}_{\mathrm{mcm}}^{\mathrm{Gln} \mathrm{s}^{2} \mathrm{UUG}}$ was treated with the indicated enzyme(s) before ligation and RT-PCR amplification. (C) The sequence shared between tRNA $\mathrm{mcm}^{5} \mathrm{~s}^{2} \mathrm{GUC}, \mathrm{tRNA}_{\mathrm{mcm}}^{\mathrm{Lys}} \mathrm{s}^{2} \mathrm{UUU}$, and tRNA $\mathrm{mcm}^{5} \mathrm{~s}^{2} \mathrm{GUG}$ in the anticodon region, and the site of $\gamma$-toxin cleavage.
$\mathrm{tRNA}_{\mathrm{mcm}^{5} \mathrm{~s}^{2} \mathrm{UUC}}^{\mathrm{Glu}}, \mathrm{tRNA} \mathrm{mcm}^{\mathrm{Lys}} \mathrm{s}^{2} \mathrm{UUU}$, and $\mathrm{tRNA}_{\mathrm{mcm}^{5} \mathrm{~s}^{2} \mathrm{GUG}}^{\mathrm{Gln}}$ (Fig. 3A). Purified tRNA $\mathrm{mcm}^{5} \mathrm{~s}^{2} U U C, \mathrm{tRNA}_{\mathrm{mcm}}^{\mathrm{Lys} \mathrm{s}^{2} \mathrm{UUU}}$, and tRNA $\mathrm{mcm}^{\mathrm{Gl}} \mathrm{s}^{2} \mathrm{UUG}$ were treated with $\gamma$-toxin, and the $5^{\prime}$ - and $3^{\prime}$ fragments of each tRNA were isolated from a denaturing polyacrylamide gel. The $3^{\prime}$ tRNA fragments could be directly labeled with $\left[\gamma^{-}{ }^{32} \mathrm{P}\right]$ ATP by using T4 polynucleotide kinase (T4 PNK), suggesting the presence of a $5^{\prime}$ hydroxyl terminus (data not shown).

To determine the $3^{\prime}$ end of the $5^{\prime}$ tRNA fragments, a procedure involving ligation of an oligonucleotide to the $3^{\prime}$ end was used. This provides a priming site for reverse transcription and subsequent PCR (Morse and Bass 1997). We obtained PCR products if the tRNA fragments were treated with T4 PNK before ligation to the oligonucleotide (Fig. 3B). No PCR product was obtained if the fragments were treated with calf intestinal alkaline phosphatase (CIP), which has $5^{\prime}$ and $3^{\prime}$ phosphatase activity. This suggests that the $\gamma$-toxin generates a $2^{\prime}, 3^{\prime}$ cyclic phosphate, since T4 PNK has a $2^{\prime}, 3^{\prime}$ cyclic phosphodiesterase activity that is not present in CIP (Morse and Bass 1997). DNA sequencing of cloned PCR products revealed that the $\gamma$-toxin cleavage occurs $3^{\prime}$ of the wobble nucleotide (data not shown). Taken together, these data show that $\gamma$-toxin cleaves tRNA $\mathrm{mcm}^{5} \mathrm{~s}^{2} \mathrm{UUC}, \mathrm{tRNA}_{\mathrm{mcm}^{5} \mathrm{~s}^{2} \mathrm{LUU}}^{\mathrm{Lys}}$, and tRNA $\mathrm{mcm}^{5} \mathrm{~s}^{2} \mathrm{UUG}$ between position 34 and 35 (Fig. 3C), generating a $2^{\prime}, 3^{\prime}$ cyclic phosphate and a $5^{\prime}$ hydroxyl group.

The cleavage mechanism of $\gamma$-toxin resembles that of the tRNA splicing endonuclease (Peebles et al. 1983; Trotta et al. 1997), although the position of cleavage is different. While $\gamma$ toxin targets mature tRNAs, the splicing endonuclease acts on precursor tRNAs that contain an intervening sequence located one nucleotide $3^{\prime}$ of the anticodon. A related mechanism is also utilized by the bacterial tRNA endonucleases, PrrC, colicin D, and colicin E5 (Amitsur et al. 1987; Ogawa et al. 1999; Tomita et al. 2000), which targets specific subsets of bacterial tRNAs. The PrrC protein cleaves tRNA ${ }^{\text {Lys }}$ $5^{\prime}$ of the wobble nucleotide (Amitsur et al. 1987). Similar to $\gamma$-toxin, the cleavage by PrrC protein is stimulated by presence of modified nucleosides in the anticodon region (Jiang et al. 2001, 2002). Colicin D cleaves all four tRNA ${ }^{\text {Arg }}$ isoacceptors $3^{\prime}$ of position 38 (Tomita et al. 2000), whereas colicin E5 cleaves $3^{\prime}$ of the wobble nucleotide in $\mathrm{tRNA}^{\mathrm{Tyr}}$, $\mathrm{tRNA}^{\mathrm{His}}$, $\mathrm{tRNA}^{\mathrm{Asn}}$, and tRNA ${ }^{\text {Asp }}$ (Ogawa et al. 1999). Even though the mechanism of cleavage by $\gamma$-toxin is similar to other tRNA endonucleases, $\gamma$-toxin shows no obvious amino acid sequence homology to any of these.

Cells exposed to zymocin arrest in the $G_{1}$ phase of the cell cycle (Butler et al. 1991b). Inhibition of protein synthesis by shifting strains with conditional mutations in genes coding for translation initiation factors or aminoacyl-tRNA synthetases to the nonpermissive condition causes a $G_{1}$ arrest (Unger and Hartwell 1976; Johnston et al. 1977; Hohmann and Thevelein 1992; Wrobel et al. 1999; Pyronnet and Sonenberg 2001). Thus, the zymocin induced $\mathrm{G}_{1}$ arrest is most likely a consequence of a translational defect caused by depletion/reduction of 
$\mathrm{tRNA}_{\mathrm{mcm}}^{\mathrm{Glu} \mathrm{s}^{2} \mathrm{UUC}}, \mathrm{tRNA}_{\mathrm{mcm}^{5} \mathrm{~s}^{2} \mathrm{UUU}}^{\mathrm{Lys}}$, and tRNA $\mathrm{mcm}^{\mathrm{G} \mathrm{s}^{2} \mathrm{UUG}}$. The $\gamma$ subunit of zymocin is the first identified eukaryotic toxin that targets tRNA. Interestingly, the $\boldsymbol{\gamma}$-toxin shows regions of similarity to a plasmid encoded protein in the toxin secreting yeast Pichia inositovora (Klassen and Meinhardt 2003). Since an elp3 mutant lacking 5 -substituted wobble uridines is less sensitive to the P. inositovora toxin (Klassen and Meinhardt 2003), the target of this toxin is probably one or several $U_{34}$ containing tRNA species. This suggests that secretion of toxins to deplete competing fungi of tRNA could be a wide spread strategy to gain a growth advantage.

\section{MATERIALS AND METHODS}

\section{Yeast strains, media, and genetic procedures}

Yeast transformation (Gietz et al. 1992), media, and genetic procedures have been described (Burke et al. 2000). Plates supplemented with $K$. lactis zymocin were prepared as described earlier (Butler et al. 1991b). All S. cerevisiae strains are derivatives of W303-1A (MATa ura3-1 leu2-3,112 trp1-1 his3-11,15 can1-100 ade2-1) or W303-1B

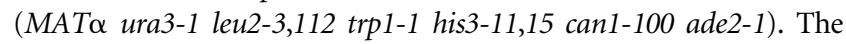
elp3::KanMX4 and trm9::KanMX4 alleles were PCR amplified from the corresponding null mutants in the yeast deletion collection (Research genetics). The PCR products were transformed into strain

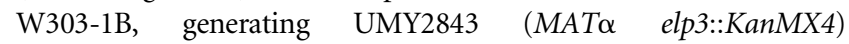
and UMY3297 (MAT $\alpha$ trm9::KanMX4). These strains were confirmed by PCR and the lack of $\mathrm{mcm}^{5}$-modified uridines in tRNA. The LYS2 open reading frame in W303-1A or W303-1B was replaced with the KanMX6- $P_{G A L 1}-\gamma$-toxin construct, generating UMY3263 (MATa lys2::KanMX6-P GAL1 $-\gamma$-toxin) and

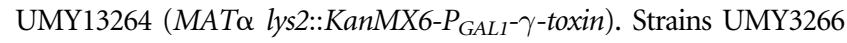

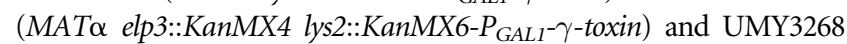

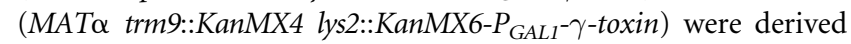
from crosses between UMY3263 (MATa lys2:: KanMX6-P $P_{G A L 1}-\gamma$ -

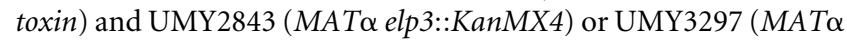
trm9::KanMX4). Strains with an integrated $P_{G A L 1}-\gamma$-toxin construct were grown to $\mathrm{OD}_{600} \sim 0.1$ in raffinose containing YEP medium. Each culture was divided into two, followed by addition of galactose (inducing condition) or raffinose (non-inducing condition).

\section{Plasmid constructions}

DNA manipulations, plasmid preparations, and bacterial transformations were performed according to standard protocols. The E. coli strain used for plasmid constructions was DH5 $\alpha$ (Bethesda Research Laboratories). Genes were PCR amplified by using Pwo DNA polymerase (Roche Applied Science). To place the $\gamma$-toxin gene under the GAL1 promoter, the $\gamma$-toxin gene (omitting codons 1-19 encoding the signal peptide) was PCR amplified from $K$. lactis killer strain 2105-1D (Gunge and Sakaguchi 1981) by using oligonucleotides $5^{\prime}$ ATCAGGATCCATGGCAGCTACTACTGCGAGA- $3^{\prime}$ and $5^{\prime}$-ACTT GAGCTCGTCATTTTATTATACACATTTTCC-3'. The PCR product was digested with BamHI/SacI and cloned into corresponding sites in pRS316- $P_{\text {GALl }}$ (Liu et al. 1992), generating plasmid pRS316$P_{G A L 1}-\gamma$-toxin (pABY1472). Plasmid pRS316-KanMX6- $P_{G A L 1}-\gamma$ toxin (pABY1637) was obtained by transforming a yeast strain carrying pRS316- $P_{G A L 1}-\gamma$-toxin with a KanMX6- $P_{G A L 1}$ DNA fragment amplified from pFA6a-KanMX6- $P_{G A L 1}-3 H A$ (Longtine et al. 1998). One oligonucleotide introduced 40 nucleotides of homology to the vector sequence of pRS316. Plasmids isolated from G418 ${ }^{\mathrm{R}}$ transformants were confirmed by restriction analysis and DNA sequencing. To construct plasmid pRS316- $P_{G A L 1}-\gamma$-toxin-GST-KanMX6 (pABY16 43), a GST-KanMX6 cassette was PCR amplified from pFA6a-GSTKanMX6 (Longtine et al. 1998) and transformed into a yeast strain carrying pRS316- $P_{G A L 1}-\gamma$-toxin. The oligonucleotides used in the PCR generated homology to sequences located 40 nucleotides upstream and downstream of the stop codon of the $\gamma$-toxin gene. Plasmids from G418 ${ }^{\mathrm{R}}$ tranformants were isolated, and the generation of an in-frame $\gamma$-toxin-GST fusion was confirmed by DNA sequencing. Wild-type yeast cells carrying this plasmid failed to grow on a galactose plate, confirming the functionality of the construct. Plasmid pETM-13- $\gamma$-toxin-GST (pABY1644) was constructed by cloning an NcoI/BglII $\gamma$-toxin-GST fragment from pRS316-P $P_{G A L 1}-\gamma$-toxin-GSTKanMX6 into the NcoI/BamHI sites of pETM-13. In this plasmid, the $\gamma$-toxin-GST fusion gene is under the T7 promoter. A control plasmid, pETM-13-GST (pAB-Y1650), was obtained by cloning an NcoI/BglII GST fragment, PCR amplified from pRS316-P $P_{G A L 1}-\gamma$-toxin-GSTKanMX6, into the NcoI/BamHI sites of pETM-13. The oligonucleotides used were $5^{\prime}$-ATGCCCATGGGGATCCCCGGGTTAATTAA- $3^{\prime}$ and $5^{\prime}$-AATACGACTCACTATAG- $3^{\prime}$. Plasmid pRS425-tE(UUC) (pABY1479) was constructed by cloning a HindIII/BamHI $t E(U U C) M$ fragment, PCR amplified from W303-1A, into the corresponding sites of the high copy vector pRS425 (Christianson et al. 1992). A BamHI/EagI $t K(U U U) L$ fragment, amplified from W303-1A, was cloned into pRS425, generating pRS425-tK(UUU) (pABY1604). The $t Q(U U G) L$ gene was amplified by PCR from W303-1A, followed by addition of an A overhang using Taq DNA polymerase (Roche Applied Science), and cloned into the pGEM-T Easy Vector (Promega), generating pGEM-T Easy- $t Q(U U G)$ (pABY1474). An ApaI/SacI $t Q(U U G) L$ fragment from pGEM-T Easy- $t Q(U U G)$ was cloned into the corresponding sites of pRS425, generating pRS425-tQ(UUG) (pABY1499). The oligonucleotides used were $5^{\prime}$-TTTTAAGCTTGAGACGTCAAGTTTC TCGTTG- $3^{\prime}$ and $5^{\prime}$-TTTTGGATCCGGTGGCGTTTTTAACTTCT TC-3' $(t E(U U C) M), \quad 5^{\prime}$-CGTAGGAT CCGGTAGAGTCTCTTCT TGGTC- $3^{\prime}$ and $5^{\prime}$-GGTTCGGCCGACCTACTAGGTACTTTAGG- $3^{\prime}$ $(t K(U U U) L), \quad$ or $\quad 5^{\prime}$-ATTAGGATCCGTTATTGTGTTTCCCGA GAGG- $3^{\prime}$ and $5^{\prime}$-AATACTCGAGAATACGCGAAGGGGAATC-3' $(t Q(U U G) L)$. A BamHI/EagI $t K(U U U)$ fragment from pRS425$t K(U U U)$ was cloned into the corresponding sites in pRS425$t E(U U C)$, generating pRS425- $t E(U U C)-t K(U U U)$ (pABY1649). Plasmid pRS425-tK(UUU)-tQ(UUG) (pABY1707) was constructed by cloning a SacI/SacII $t Q(U U G)$ fragment from pGEMT Easy- $t Q(U U G)$ into corresponding sites of pRS425-tK(UUU). A SacI/SacII $t Q(U U G)$ fragment from pGEM-T Easy- $t Q(U U G)$ was cloned into the corresponding sites of pRS425- $t E(U U C)$, generating pRS425- $t E(U U C)-t Q(U U G)$ (pABY1661). The $t Q(U U G)$ gene was cloned from pGEM-T Easy- $t Q(U U G)$ as a SacI/SacII fragment into the corresponding sites in pRS425- $t E(U U C)-t K(U U U)$, generating pRS425- $t E(U U C)-t K(U U U)-t Q(U U G)$ (pABY1653).

\section{RNA preparation and Northern blot analysis}

Total tRNA for in vitro $\gamma$-toxin treatment was isolated from exponentially growing cultures of W303-1B, UMY2843, or UMY3294 (Huang et al. 2005). Single tRNA species were isolated 
from W303-1A total tRNA as described previously (Huang et al. 2005). Total RNA was prepared by using hot phenol (Ausubel et al. 2001). Approximately $5 \mu \mathrm{g}$ of total tRNA or RNA were separated on $8 \%$ polyacrylamide, $8 \mathrm{M}$ urea gels, and transferred to Zeta-Probe membranes (Bio-Rad). Oligonucleotides used to detect tRNAs were $5^{\prime}$-GCCCAAGAGATTTCGAGTCTCT- $3^{\prime} \quad$ (tRNA (RGA $\left._{\text {Ser }}\right), \quad 5^{\prime}$ CTCCGCTACGGGGAGTCGAAC-3' (tRNA $3_{\text {mcm }}^{\text {Glu }}$ suUC $^{\prime 2} 3^{\prime}$ probe), $5^{\prime}$-AGCCGTTACACTATATCGGA-3' (tRNA mcm $^{\mathrm{Glu}} \mathrm{s}^{2} \mathrm{UUC} 5^{\prime}$ probe), $5^{\prime}$ CTCCTCATAGGGGGCTC-3' (tRNA mcm $^{\mathrm{Lys}} \mathrm{s}^{2} \mathrm{UuU} 3^{\prime}$ probe), $5^{\prime}$-CAACT GAGCTAACAAGGA-3' (tRNA mcm $^{\text {Lys }} \mathrm{s}^{2} \mathrm{UUU} 5^{\prime}$ probe), $5^{\prime}$-AGGTCC TACCCGGATTC- $3^{\prime}$ (tRNA $\mathrm{mcm}^{\mathrm{Gln}} \mathrm{s}^{2} \mathrm{UUG} 3^{\prime}$ probe), and $5^{\prime}$-CCAC TACACTATAGGACC- $3^{\prime}$ ( $\mathrm{tRNA}_{\mathrm{mcm}^{5} \mathrm{~s}^{2} \mathrm{UUG}}^{\mathrm{Gln}} 5^{\prime}$ probe). Oligonucleotides were labeled by using adenosine $\left[\gamma^{32} \mathrm{P}\right]$-triphosphate $(6000$ $\mathrm{Ci} / \mathrm{mmol}$, Amersham Biosciences) and polynucleotide kinase (Roche Applied Science). Northern blots were visualized and quantified by Phosphor-Imager analysis.

\section{Purification of the $\gamma$-toxin-GST fusion protein}

A total volume of $20 \mathrm{~mL}$ of $\mathrm{LB}$ medium containing $50 \mu \mathrm{g} / \mathrm{mL}$ of kanamycin was inoculated with E. coli strain BL21 (DE3) (Novagen) carrying pETM-13- $\gamma$-toxin-GST or pETM-13-GST and grown to $\mathrm{OD}_{600} \sim 2.0$ at $30^{\circ} \mathrm{C}$. The $\gamma$-toxin-GST and GST proteins were purified from cell extracts by using Glutathione-Sepharose 4B (Amersham Biosciences) according to manufacturer's instructions. The purified proteins were applied onto a Sephacryl S200HR XK26 column (Amersham Biosciences) and fractionated by using a buffer containing $20 \mathrm{mM}$ Hepes ( $\mathrm{pH} 7.3$ ), $0.2 \mathrm{mM}$ EDTA, $150 \mathrm{mM} \mathrm{NaCl}$, and protease inhibitors (Roche Applied Science). Collected fractions were monitored by using Coomassie Plus protein assay reagent (Pierce) and silver staining of SDSPAGE-separated aliquots.

\section{Characterization of tRNAs treated with $\gamma$-toxin in vitro}

Purified $\gamma$-toxin-GST protein was mixed with total or purified tRNA in $10 \mathrm{mM}$ Tris- $\mathrm{HCl}, 10 \mathrm{mM} \mathrm{MgCl}_{2}, 50 \mathrm{mM} \mathrm{NaCl}$, and $1 \mathrm{mM}$ dithiothreitol ( $\mathrm{pH} 7.5)$ and incubated for $10 \mathrm{~min}$ at $30^{\circ} \mathrm{C}$. The samples were precipitated and the pellets dissolved in water. The $5^{\prime}$-end of the $3^{\prime}$ halves of $\mathrm{tRNA}_{\mathrm{mcm}^{5} \mathrm{~s}^{2} \mathrm{GUC}}^{\mathrm{Glu}} \mathrm{tRNA}_{\mathrm{mcm}^{5} \mathrm{~s}^{2} \mathrm{LUU}}^{\mathrm{Lys}}$, and $\mathrm{tRNA}_{\mathrm{mcm}^{5} \mathrm{~s}^{2} U U \mathrm{G}}^{\mathrm{Gln}}$ were determined by primer extension analysis. Appropriate tRNA samples $(1 \mu \mathrm{g})$ were mixed with 5 pmol of ${ }^{32} \mathrm{P}$-kinased oligonucleotides, $5^{\prime}$-CTCCGCTACGGGGAGTCGAAC- $3^{\prime} \quad\left(\mathrm{tRNA}_{\mathrm{mcm}^{5} \mathrm{~s}^{2} \mathrm{UUC}}^{\mathrm{Glu}}\right), \quad 5^{\prime}-$ CTCCTCATAGGGGGCTC- $3^{\prime}$ (tRNA $\left.\mathrm{mcm}^{\mathrm{Lys} \mathrm{s}^{2} \mathrm{UUU}}\right)$, or $5^{\prime}$-AGGTCC TACCCGGATTC- $3^{\prime}$ (tRNA $\mathrm{mcm}^{5} \mathrm{~s}^{2} \mathrm{UUG}$ ) in AMV reverse transcriptase buffer (Roche Applied Science). Primers were annealed to the templates by incubating for $3 \mathrm{~min}$ at $70^{\circ} \mathrm{C}$ and for $5 \mathrm{~min}$ at $37^{\circ} \mathrm{C}$ and thereafter were placed on ice. Extensions were performed for $5 \mathrm{~min}$ at $37^{\circ} \mathrm{C}$ in the presence of $20 \mu \mathrm{M}$ dNTPs and $25 \mathrm{U}$ of AMV reverse transcriptase (Roche Applied Science). Reactions were stopped by addition of $35 \mu \mathrm{L} 0.3 \mathrm{M} \mathrm{NaAc}(\mathrm{pH} 5.2)$ containing $0.1 \mathrm{mg} / \mathrm{mL}$ RNase $\mathrm{A}$ and were incubated $15 \mathrm{~min}$ at $37^{\circ} \mathrm{C}$. The samples were precipitated and applied next to a sequencing ladder on a denaturing $6 \%$ polyacrylamide gel. The ladder was obtained by sequencing a $\mathrm{tRNA}_{\mathrm{mcm}^{5} \mathrm{~s}^{2} \mathrm{UUC}}^{\mathrm{Glu}}$ gene using the oligonucleotide $5^{\prime}$ CTCCGCTACGGGGAGTCGAAC- $3^{\prime}$.

The purified $5^{\prime}$ tRNA fragments were incubated in the presence or absence of $10 \mathrm{U}$ of T4 PNK (USB) as described previously (Amitsur et al. 1987). After this, the samples were treated with
20 U of CIP (Roche Applied Science) according to manufacturer's instructions. A kinased oligonucleotide 5'-GACATACGTACGAC GAGTACTGACCAGCTACGATGCATGAGCGCCTGddA-3' was ligated to the dephosphorylated tRNA fragments as earlier described (Morse and Bass 1997), except the reaction contained $1 \mathrm{mM}$ ATP. Following reverse transcription as described above, the cDNA was PCR amplified by using Taq DNA polymerase (Roche Applied Science). The oligonucleotides were $5^{\prime}$ CAGGCGCTCATGCAT-3' (RT and PCR), 5' ${ }^{\prime}$-TCCGATATAGTG TAACG-3' (PCR for tRNA $\left.\mathrm{mcm}^{\mathrm{Glu}} \mathrm{s}^{2} \mathrm{UUC}\right), 5^{\prime}$-TCCTTGTTAGCT CAGTT-3' (PCR for tRNA mcm $^{\text {Lys }} \mathrm{s}^{2} \mathrm{UUU}$ ), and 5'-GGTCCTATAGTG TAGTG-3' (PCR for tRNA $\mathrm{mcm}^{5} \mathrm{~s}^{2} \mathrm{UUG}$ ). PCR products from two independent reactions for each tRNA were cloned by using the TOPO TA Cloning Kit (Invitrogen) and the DNA sequenced by using DYEnamic ET Dye Terminator Cycle Sequencing Kit.

\section{ACKNOWLEDGMENTS}

We thank Drs. L. Symington and K. Arndt for S. cerevisiae strains W303-1A, W303-1B, and CY4029. Dr. N. Gunge is acknowledged for K. lactis strain 2105-1D. Drs. G.R. Björk, H. Wolf-Watz, and S. Tuck are acknowledged for valuable discussions. This work was financially supported by the Swedish Research Council (621-20042563) and the Swedish Cancer Society (3516-B03-10XAB). M.J.O.J. was supported by grants from the Swedish Research Council (621-2004-1700) and the Swedish Cancer Society (0608B04-33XAB).

Received July 25, 2005; accepted August 22, 2005.

\section{REFERENCES}

Amitsur, M., Levitz, R., and Kaufmann, G. 1987. Bacteriophage T4 anticodon nuclease, polynucleotide kinase and RNA ligase reprocess the host lysine tRNA. EMBO J. 6: 2499-2503.

Ausubel, F.M., Brent, R., Kingston, R.E., Moore, D.D., Seidman, J.G., Smith, J.A., and Struhl, K. 2001. Current protocols in molecular biology. John Wiley and Sons, New York.

Burke, D., Dawson, D., and Stearns, T. 2000. Methods in yeast genetics. Cold Spring Harbor Laboratory Press, Cold Spring Harbor, New York.

Butler, A.R., Porter, M., and Stark, M.J. 1991a. Intracellular expression of Kluyveromyces lactis toxin $\gamma$ subunit mimics treatment with exogenous toxin and distinguishes two classes of toxin-resistant mutant. Yeast 7: 617-625.

Butler, A.R., White, J.H., and Stark, M.J. 1991b. Analysis of the response of Saccharomyces cerevisiae cells to Kluyveromyces lactis toxin. J. Gen. Microbiol. 137: 1749-1757.

Butler, A.R., White, J.H., Folawiyo, Y., Edlin, A., Gardiner, D., and Stark, M.J. 1994. Two Saccharomyces cerevisiae genes which control sensitivity to $\mathrm{G}_{1}$ arrest induced by Kluyveromyces lactis toxin. Mol. Cell. Biol. 14: 6306-6316.

Christianson, T.W., Sikorski, R.S., Dante, M., Shero, J.H., and Hieter, P. 1992. Multifunctional yeast high-copy-number shuttle vectors. Gene 110: 119-122.

Frohloff, F., Fichtner, L., Jablonowski, D., Breunig, K.D., and Schaffrath, R. 2001. Saccharomyces cerevisiae Elongator mutations confer resistance to the Kluyveromyces lactis zymocin. EMBO J. 20: 1993-2003.

Gietz, D., St. Jean, A., Woods, R.A., and Schiestl, R.H. 1992. Improved method for high efficiency transformation of intact yeast cells. Nucleic Acids Res. 20: 1425.

Gunge, N. and Sakaguchi, K. 1981. Intergeneric transfer of deoxyribonucleic acid killer plasmids, pGK11 and pGK12, from Kluyver- 
omyces lactis into Saccharomyces cerevisiae by cell fusion. J. Bacteriol. 147: 155-160.

Gunge, N., Tamaru, A., Ozawa, F., and Sakaguchi, K. 1981. Isolation and characterization of linear deoxyribonucleic acid plasmids from Kluyveromyces lactis and the plasmid-associated killer character. J. Bacteriol. 145: 382-390.

Hohmann, S. and Thevelein, J.M. 1992. The cell division cycle gene CDC60 encodes cytosolic leucyl-tRNA synthetase in Saccharomyces cerevisiae. Gene 120: 43-49.

Huang, B., Johansson, M.J.O., and Byström, A.S. 2005. An early step in wobble uridine tRNA modification requires the Elongator complex. RNA 11: 424-436.

Jablonowski, D., Frohloff, F., Fichtner, L., Stark, M.J., and Schaffrath, R. 2001. Kluyveromyces lactis zymocin mode of action is linked to RNA polymerase II function via Elongator. Mol. Microbiol. 42: 1095-1105.

Jiang, Y., Meidler, R., Amitsur, M., and Kaufmann, G. 2001. Specific interaction between anticodon nuclease and the tRNA(Lys) wobble base. J. Mol. Biol. 305: 377-388.

Jiang, Y., Blanga, S., Amitsur, M., Meidler, R., Krivosheyev, E., Sundaram, M., Bajji, A.C., Davis, D.R., and Kaufmann, G. 2002. Structural features of tRNALys favored by anticodon nuclease as inferred from reactivities of anticodon stem and loop substrate analogs. J. Biol. Chem. 277: 3836-3841.

Johansson, M.J.O. and Byström, A.S. 2005. Transfer RNA modifications and modifying enzymes in Saccharomyces cerevisiae. In Finetuning of RNA functions by modification and editing (ed. H. Grosjean), pp. 87-120. Springer-Verlag, New York.

Johnston, G.C., Pringle, J.R., and Hartwell, L.H. 1977. Coordination of growth with cell division in the yeast Saccharomyces cerevisiae. Exp. Cell Res. 105: 79-98.

Kalhor, H.R. and Clarke, S. 2003. Novel methyltransferase for modified uridine residues at the wobble position of tRNA. Mol. Cell. Biol. 23: 9283-9292.

Klassen, R. and Meinhardt, F. 2003. Structural and functional analysis of the killer element pPin1-3 from Pichia inositovora. Mol. Genet. Genomics 270: 190-199.

Liu, H., Krizek, J., and Bretscher, A. 1992. Construction of a GAL1regulated yeast cDNA expression library and its application to the identification of genes whose overexpression causes lethality in yeast. Genetics 132: 665-673.

Longtine, M.S., McKenzie III, A., Demarini, D.J., Shah, N.G., Wach, A., Brachat, A., Philippsen, P., and Pringle, J.R. 1998. Additional modules for versatile and economical PCR-based gene deletion and modification in Saccharomyces cerevisiae. Yeast 14: 953-961.

Morse, D.P. and Bass, B.L. 1997. Detection of inosine in messenger RNA by inosine-specific cleavage. Biochemistry 36: 8429-8434.
Ogawa, T., Tomita, K., Ueda, T., Watanabe, K., Uozumi, T., and Masaki, H. 1999. A cytotoxic ribonuclease targeting specific transfer RNA anticodons. Science 283: 2097-2100.

Otero, G., Fellows, J., Li, Y., de Bizemont, T., Dirac, A.M., Gustafsson, C.M., Erdjument-Bromage, H., Tempst, P., and Svejstrup, J.Q. 1999. Elongator, a multisubunit component of a novel RNA polymerase II holoenzyme for transcriptional elongation. Mol. Cell 3: 109-118.

Peebles, C.L., Gegenheimer, P., and Abelson, J. 1983. Precise excision of intervening sequences from precursor tRNAs by a membraneassociated yeast endonuclease. Cell 32: 525-536.

Pyronnet, S. and Sonenberg, N. 2001. Cell-cycle-dependent translational control. Curr. Opin. Genet. Dev. 11: 13-18.

Rahl, P.B., Chen, C.Z., and Collins, R.N. 2005. Elp1p, the yeast homolog of the FD disease syndrome protein, negatively regulates exocytosis independently of transcriptional elongation. Mol. Cell 17: 841-853.

Schaffrath, R. and Meinhardt, F. 2005. Kluveromyces lactis zymocin and other plasmid-encoded yeast killer toxins. In Microbial protein toxins (eds. Schmitt M.J. and Schaffrath R.), pp. 133-155. Springer-Verlag, Berlin.

Stark, M.J., Boyd, A., Mileham, A.J., and Romanos, M.A. 1990. The plasmid-encoded killer system of Kluyveromyces lactis: A review. Yeast 6: 1-29.

Sugisaki, Y., Gunge, N., Sakaguchi, K., Yamasaki, M., and Tamura, G. 1983. Kluyveromyces lactis killer toxin inhibits adenylate cyclase of sensitive yeast cells. Nature 304: 464-466.

Tokunaga, M., Kawamura, A., and Hishinuma, F. 1989. Expression of pGKL killer $28 \mathrm{~K}$ subunit in Saccharomyces cerevisiae: Identification of $28 \mathrm{~K}$ subunit as a killer protein. Nucleic Acids Res. 17: 3435-3446.

Tomita, K., Ogawa, T., Uozumi, T., Watanabe, K., and Masaki, H. 2000. A cytotoxic ribonuclease which specifically cleaves four isoaccepting arginine tRNAs at their anticodon loops. Proc. Natl. Acad. Sci. 97: 8278-8283.

Trotta, C.R., Miao, F., Arn, E.A., Stevens, S.W., Ho, C.K., Rauhut, R., and Abelson, J.N. 1997. The yeast tRNA splicing endonuclease: A tetrameric enzyme with two active site subunits homologous to the archaeal tRNA endonucleases. Cell 89: 849-858.

Unger, M.W. and Hartwell, L.H. 1976. Control of cell division in Saccharomyces cerevisiae by methionyl-tRNA. Proc. Natl. Acad. Sci. 73: 1664-1668.

White, J.H., Butler, A.R., and Stark, M.J.R. 1989. Kluyveromyces lactis toxin does not inhibit yeast adenylyl cyclase. Nature 341: 666-668.

Wrobel, C., Schmidt, E.V., and Polymenis, M. 1999. CDC64 encodes cytoplasmic alanyl-tRNA synthetase, Alalp, of Saccharomyces cerevisiae. J. Bacteriol. 181: 7618-7620. 

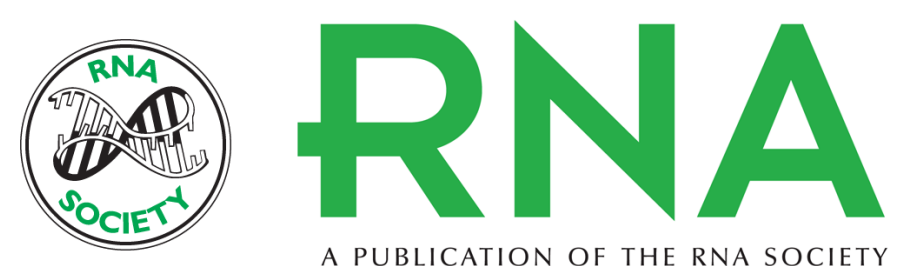

A PUBLICATION OF THE RNA SOCIETY

\section{The Kluyveromyces lactis $\gamma$-toxin targets tRNA anticodons}

JIAN LU, BO HUANG, ANDERS ESBERG, et al.

RNA 2005 11: 1648-1654

References This article cites 33 articles, 12 of which can be accessed free at: http://rnajournal.cshlp.org/content/11/11/1648.full.html\#ref-list-1

\section{License}

Email Alerting Service

Receive free email alerts when new articles cite this article - sign up in the box at the top right corner of the article or click here. 